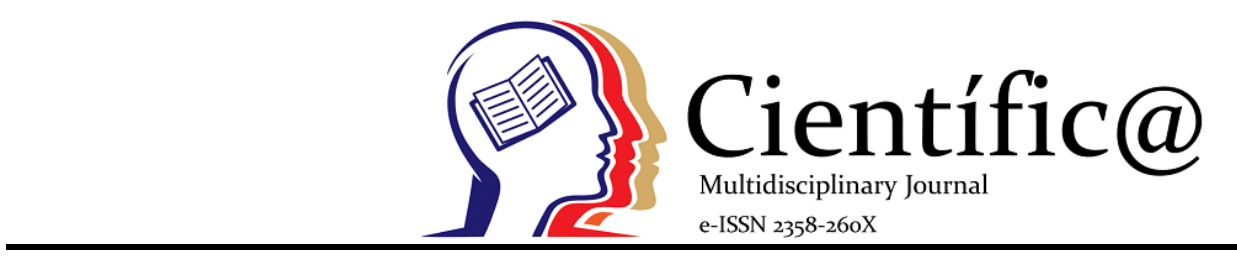

\title{
COMPARISON OF PRODUCTION COSTS IN PEQUI CULTURE (Caryocar brasiliense Camb.)
}

\author{
COMPARATIVO DOS CUSTOS DE PRODUÇÃO DO PEQUIZEIRO (Caryocar brasiliense Camb.) \\ Matheus Vinicius Abadia Ventura ${ }^{1 *}$, Hellen Regina Fernandes Batista ${ }^{1}$; Marcio Moacir Bessa ${ }^{3}$ \\ ${ }^{1}$. Instituto Federal Goiano - campus Rio Verde, Brasil - matheusvinicius10@hotmail.com \\ 2. Universidade Estadual Paulista Júlio de Mesquita Filho, São Paulo, Brasil..
}

\section{Info}

Recebido: 03/2020

Publicado: 06/2020

DOI: $10.29247 / 2358-260 X .2020 v 7 i 1.4470$

ISSN: 2358-260X

\section{Palavras-Chave}

pequi, cerrado, unidade de

comercialização, hectare

Keywords:

pequi, cerrado, commercialization unit, hectare.

\begin{abstract}
The cerrado is one of the main biomes belonging to the Brazilian territory. Among the species present in this biome is the pequizeiro (Caryocar brasiliense Camb). In general, even with extractive exploitation, several families benefit from the pequi crop, with culture as a source of income and employment, and up to $57 \%$ of the annual income of rural workers in the cerrado is evidenced by the commercialization of fruits in the region. In view of this, the objective of this work was to compare the production costs of the pequizeiro in four Brazilian cities, Pocone, in Mato Grosso, Japonvar, in Minas Gerais Iporá, in
\end{abstract} Goias and Crato, in Ceará in the agricultural years 2017 and 2018. The greatest reduction in production costs, per commercialization unit and per hectare of the agricultural year from 2017 to 2018 was in the municipality of Japonvar, MG. In the municipality of Iporá, GO, there was an increase in the production cost per commercialization unit and per hectare of the agricultural year from 2017 to 2018 . The municipality of Japonvar, MG, among the cities analyzed, has the highest profitability in the pequizeiro culture.

\section{Resumo}

O cerrado é um dos principais biomas pertencentes ao território brasileiro. Entre as espécies presentes neste bioma está o pequizeiro (Caryocar brasiliense Camb). De maneira geral, mesmo com a exploração extrativa, várias famílias se beneficiam da safra de pequi, tendo a cultura como fonte de renda e emprego, sendo que até $57 \%$ da renda anual dos trabalhadores rurais do cerrado é evidenciada pela comercialização dos frutos da região. Diante disto, objetivou-se com esse trabalho, comparar os custos de produção do pequizeiro em quatros cidades brasileiras, Poconé, no Mato Grosso, Japonvar, em Minas Gerais Iporá, em Goiás e Crato, no Ceará nos anos agrícolas 2017 e 2018. A maior redução de custo de produção, por unidade de comercialização e por hectare do ano agrícola de 2017 para 2018 foi no município de Japonvar, MG. No município de Iporá, GO houve aumento no custo de produção por unidade de comercialização e por hectare do ano agrícola de 2017 para 2018. 0 município de Japonvar, MG, entre as cidades analisadas, apresenta a maior lucratividade na cultura do pequizeiro.

\section{INTRODUCTION}

The cerrado is one of the main biomes belonging to the Brazilian territory, with an area of about two million $\mathrm{km}^{2}$, occupying a large part of the Northeast, Midwest and Southeast regions (SANTOS et al., 2013; GARCIA et al., 2017). 
Among the species present in this biome is the pequizeiro (Caryocar brasiliense Camb). The pequizeiro or pequi is a typical Brazilian species, belonging to the family Caryocaraceae, with tree size that can vary from 8 to $12 \mathrm{~m}$ in height (CAMARGO et al., 2014).

The pequizeiro fruits consist of a greenishcolored epicarp, coloring the outer mesocarp that comes out yellowish and whitish. At the center of the fruit seed, also known as pyrene and putamen, fleshy with an inner core (corresponding to the pulp), rich in oil, yellow or orange, a stony endocarp covered with a core and covered with spines (GARCIA et al., 2017).

This fruit is widely used as a food source and can be consumed fresh or cooked, in the preparation of sweet or savory foods, being a source of lipids, proteins, vitamins (A and C) and minerals (BOAS et al., 2013; RODRIGUES et al., 2016).

Although the exploitation of these fruits is seasonal, especially in rural areas, the economic contribution of this activity is much greater than that indicated by official statistics, being the complement of the income of several farming families (FELFILI et al., 2004; RIBEIRO et al., 2008).

In general, even with extractive exploitation, several families benefit from the pequi crop, with culture as a source of income and employment (SILVA, 2009 ), and up to $57 \%$ of the annual income of rural workers in the cerrado is evidenced by the commercialization of the region's fruits (GOMES, 2000; OLIVEIRA, 2006), and in the north of Minas Gerais, $17.73 \%$ of the family income of the producers is represented by the commercialization of pequi (POZO, 1997) and in Goias, it can reach up to $80 \%$ of the family income of the farmer (SANTOS et al., 2013).

Given the above, this work aimed to compare the costs of production of the pequizeiro in four Brazilian cities, Pocone, in Mato Grosso, Japonvar, in
Minas Gerais, Ipora, in Goias and Crato, in Ceara in the agricultural years 2017 and 2018.

\section{MATERIAL AND METHODS}

As for the technical procedures used in this study, descriptive research was carried out with statistical data provided by the Agricultural Information Portal at the Agricultural Observatory of the National Supply Company (CONAB, 2018).

Statistical data were analyzed in the agricultural years of 2017 and 2018, of the pequizeiro culture (Caryocar brasiliense Camb.) In four Brazilian municipalities. The municipalities were Pocone, in Mato Grosso (MT), located at latitude: $16^{\circ} 15$ '24 "S and longitude: $56^{\circ} 37^{\prime} 22^{\prime \prime} \mathrm{W}$, in Japonvar, Minas Gerais (MG), located at latitude: $15^{\circ} 59$ '41 "S and longitude: $44^{\circ} 16$ '12" W, in Ipora, Goias (GO) located at latitude: $16^{\circ} 26^{\prime} 31$ "S and longitude: $51^{\circ} 07^{\prime} 04^{\prime \prime} \mathrm{W}$ and Crato, Ceara (CE) located at latitude: $07^{\circ} 14$ '03 "S and longitude: $39^{\circ} 24^{\prime} 34^{\prime \prime} \mathrm{W}$.

In production costs, the costs of the following items were considered: (a) administrator: consists of the rural producer, whose objective is to plan; to control; decide; monitor or control the results of the rural property; (b) Packaging (only in the municipalities of Pocone - MT, and Ipora - GO): they are tools used to sell the product to the final consumer; (c) manpower: manual worker generally employed in the production of the pequizeiro culture; (d) financing interest: rate from the financing made by the producer with credit concessionaires; (e) CESSR: special contribution to rural social security; (f) administrative expenses: expenses with telephone bills, reception, cleaning, and others; (g) external transport (only in the municipalities of Pocone - MT, Japonvar - MG, and Ipora-GO): displacement in transport to sell the product.

In both municipalities, production costs will be described per commercialization unit $(\mathrm{R} \$ / 25 \mathrm{~kg})$ and 
per hectare $(\mathrm{R} \$ / \mathrm{ha})$ in two agricultural years: 2017 and 2018, as a reference for the months of July 2017 and August 2018, respectively.

The productivity per hectare (t/ha) and the cost of production per hectare ( $\mathrm{R} \$ / \mathrm{ha}$ ) in the two agricultural years in the four Brazilian municipalities will be analyzed, in order to establish a ratio obtained by dividing the productivity by the production cost. The data obtained were tabulated by an electronic spreadsheet and presented in the form of tables.

\section{RESULTS AND DISCUSSION}

In Table 01, the production cost in Pocone, MT per commercialization unit decreased by $2.2 \%(\mathrm{R} \$ 0.40)$ and per hectare, it decreased by $2.1 \%(\mathrm{R} \$ 288)$. When looking at the data, it is noted that the reduction is related to the reduction of the special contribution to rural social security (CESSR). Pequi production in Pocone, MT in 2018 was 3 ton $(\mathrm{t})$ with a production value of R $\$ 4,000.00$ (BRASIL, 2018a).

Table 1. Production cost per commercialization unit and per hectare of pequizeiro in two agricultural years in the municipality of Pocone, MT.

\begin{tabular}{|c|c|c|c|c|}
\hline \multirow[b]{2}{*}{ Item Cost } & \multicolumn{2}{|c|}{2017} & \multicolumn{2}{|c|}{2018} \\
\hline & $\begin{array}{l}\text { Commercialization } \\
\text { Unit Cost }(\mathrm{R} \$ / 25 \mathrm{~kg})\end{array}$ & $\begin{array}{l}\text { Cost per } \\
\text { hectare } \\
(\mathrm{R} \$ / \text { ha })\end{array}$ & $\begin{array}{c}\text { Commercialization Unit } \\
\text { Cost }(\mathrm{R} \$ / 25 \mathrm{~kg})\end{array}$ & $\begin{array}{l}\text { Cost per } \\
\text { hectare } \\
(\mathrm{R} \$ / \mathrm{ha})\end{array}$ \\
\hline ADMINISTRATOR & 0.04 & 28.11 & 0.04 & 28.62 \\
\hline PACKAGING & 0.42 & 306.69 & 0.42 & 306.69 \\
\hline $\begin{array}{l}\text { MANPOWER } \\
\text { FINANCING }\end{array}$ & 14.54 & $10,687.50$ & 14.54 & $10,687.50$ \\
\hline INTEREST & 0.16 & 117.47 & 0.15 & 111.97 \\
\hline $\begin{array}{l}\text { CESSR } \\
\text { ADMINISTRATIVE }\end{array}$ & 0.59 & 431.08 & 0.20 & 147.66 \\
\hline $\begin{array}{l}\text { COSTS } \\
\text { EXTERNAL }\end{array}$ & 0.45 & 330.67 & 0.45 & 330.68 \\
\hline TRANSPORT & 2.41 & $1,771.88$ & 2.41 & $1,771.88$ \\
\hline TOTAL COST & 18.61 & $13,673.40$ & 18.21 & $13,385.00$ \\
\hline
\end{tabular}

Data from a collection carried out in the municipality of Pocone, in Mato Grosso in July 2017 and August 2018. Adapted from CONAB (2018).

According to Melo et al. (2016), 27\% of family farmers plant fruit trees (bananas, watermelons, pequi ...), with $93 \%$ of farming families practicing more than one production system in production units (MENDES et al., 2014), with $41 \%$ of activities, farmers plant to commercialize maize, manioc, pumpkin, sweet potato, banana, pequi, among others (MELO et al., 2016).

In Table 02, the production cost in Japonvar, MG per commercialization unit decreased by $14.2 \%$ $(\mathrm{R} \$ 2.12)$ and per hectare, it decreased by $14.1 \%(\mathrm{R} \$$ 615.37). Note that the biggest reductions were the cost of labor, financing interest, CESSR, and administrative

expenses. Pequi production in Japonvar, MG in 2017 was $1,124 \mathrm{t}$ with a production value of $\mathrm{R} \$ 786,000.00$ (BRASIL, 2017a) and 2018 was 1,255 $\mathrm{t}$ with a production value of $\mathrm{R} \$ 815,000.00$ (BRASIL, 2018b).

The processing of pequi involves the use of labor, without the need to leave the community, allowing to increase the market value of products and extend the time of commercialization of the pulp (AFONSO et al., 2014). 
Table 2. Production cost per commercialization unit and per hectare of the pequizeiro in two agricultural years in the municipality of Japonvar, MG.

\begin{tabular}{lcccc}
\hline \multicolumn{2}{c}{2017} & \multicolumn{2}{c}{2018} & \\
\hline Item Cost & $\begin{array}{c}\text { Commercialization } \\
\text { Unit Cost }(\mathrm{R} \$ / 25 \mathrm{~kg})\end{array}$ & $\begin{array}{c}\text { Cost per } \\
\text { hectare } \\
(\mathrm{R} \$ / \mathrm{ha})\end{array}$ & $\begin{array}{c}\text { Commercialization } \\
\text { Unit Cost }(\mathrm{R} / 25 \mathrm{~kg})\end{array}$ & $\begin{array}{c}\text { Cost per hectare } \\
(\mathrm{R} \$ / \text { ha })\end{array}$ \\
\hline ADMINISTRATOR & 0.10 & 28.11 & 0.10 & 28.62 \\
MANPOWER & 13.85 & $4,050.00$ & 12.31 & $3,600.00$ \\
FINANCING INTEREST & 0.15 & 41.75 & 0.05 & 13.82 \\
CESSR & 0.74 & 215.30 & 0.31 & 90.83 \\
ADMINISTRATIVE COSTS & 0.42 & 122.34 & 0.37 & 108.86 \\
EXTERNAL TRANSPORT & 1.75 & 511.88 & 1.75 & 511.88 \\
\hline TOTAL COST & $\mathbf{1 7 . 0 1}$ & $\mathbf{4 . 9 6 9 . 3 8}$ & $\mathbf{1 4 . 8 9}$ & $\mathbf{4 , 3 5 4 . 0 1}$ \\
\hline
\end{tabular}

Data from a collection carried out in the municipality of Japonvar, in Minas Gerais in July 2017 and August 2018. Adapted from CONAB (2018).

Table 3. Production cost per commercialization unit and per hectare of the pequizeiro in two agricultural years in the municipality of Ipora, GO.

\begin{tabular}{lcccc}
\hline \multicolumn{3}{c}{2017} & \multicolumn{2}{c}{2018} \\
\hline Item Cost & $\begin{array}{c}\text { Commercialization Unit } \\
\text { Cost }(\mathrm{R} \$ / 25 \mathrm{~kg})\end{array}$ & $\begin{array}{c}\text { Cost per hectare } \\
(\mathrm{R} \$ / \mathrm{ha})\end{array}$ & $\begin{array}{c}\text { Commercialization } \\
\text { Unit Cost }(\mathrm{R} \$ / 25 \mathrm{~kg})\end{array}$ & $\begin{array}{c}\text { Cost per hectare } \\
(\mathrm{R} \$ / \mathrm{ha})\end{array}$ \\
\hline ADMINISTRATOR & 0,02 & 18,74 & 0,02 & 19,08 \\
PACKAGING & 0,25 & 152,50 & 0,25 & 165,00 \\
MANPOWER & 14,00 & $11.250,00$ & 14,75 & $12.000,00$ \\
FINANCING INTEREST & 0,03 & 71,16 & 0,03 & 76,81 \\
CESSR & 0,25 & 288,76 & 0,25 & 151,88 \\
ADMINISTRATIVE & 0,50 & 342,64 & 0,50 & 365,52 \\
COSTS & 1,50 & $1.232,00$ & 2,00 & $1.540,00$ \\
EXTERNAL TRANSPORT & $\mathbf{1 6 , 5 5}$ & $\mathbf{1 3 . 3 5 5 , 8 0}$ & $\mathbf{1 7 , 8 0}$ & $\mathbf{1 4 . 3 1 8 , 2 9}$ \\
\hline TOTAL COST & & &
\end{tabular}

Data from a collection carried out in the municipality of Iporá, Goiás in July 2017 and August 2018. Adapted from CONAB (2018).

In Table 03 , the production cost in Ipora, GO per commercialization unit increased by $7 \%(\mathrm{R} \$ 1.25)$ and per hectare increased by $6.7 \%$ (R $\$ 962.49)$. Despite the reduction in the cost of CESSR, there is a marked increase in the cost of labor and external transportation. According to Oliveira et al. (2005), Ipora and Gulias et al. (2008), Damianopolis are pequi productive chains in the State of Goias, it stands out as an activity of social inclusion for absorbing low qualified labor and aboveaverage remuneration in relation to agricultural activities (OLIVEIRA et al., 2017).
In Table 04, the production cost in Crato, CE per commercialization unit decreased by $4.1 \%(\mathrm{R} \$ 0.73)$ and per hectare, it decreased by $3.7 \%(\mathrm{R} \$ 88.24)$. Despite the increase in labor costs, the reduction in financing interest and CESSR showed a reduction in the total cost. Pequi production in Crato, CE in 2017 was $345 \mathrm{t}$ with a production value of $\mathrm{R} \$ 338,000.00$ (BRASIL, 2017b) and 2018 was $303 \mathrm{t}$ with a production value of $\mathrm{R} \$ 303,000.00$ (BRASIL, 2018c). 
Table 4. Production cost per commercialization unit and per hectare of the pequizeiro in two agricultural years in the municipality of Crato, CE.

\begin{tabular}{lcccc}
\hline & \multicolumn{2}{c}{2017} & \multicolumn{2}{c}{2018} \\
\hline Item Cost & $\begin{array}{c}\text { Commercialization Unit } \\
\text { Cost }(\mathrm{R} \$ / 25 \mathrm{~kg})\end{array}$ & $\begin{array}{c}\text { Cost per } \\
\text { hectare } \\
(\mathrm{R} \$ / \mathrm{ha})\end{array}$ & $\begin{array}{c}\text { Commercialization } \\
\text { Unit Cost }(\mathrm{R} \$ / 25 \mathrm{~kg})\end{array}$ & $\begin{array}{c}\text { Cost per } \\
\text { hectare } \\
(\mathrm{R} \$ / \mathrm{ha})\end{array}$ \\
\hline ADMINISTRATOR & 0.25 & 18.74 & 0.25 & 19.08 \\
MANPOWER & 15.50 & $2,115.00$ & 16.50 & $2,250.00$ \\
FINANCING INTEREST & 0.25 & 33.08 & 0.03 & 10.64 \\
CESSR & 1.75 & 235.98 & 0.25 & 30.78 \\
ADMINISTRATIVE COSTS & 0.50 & 64.01 & 0.50 & 68.07 \\
\hline \multicolumn{1}{c}{ TOTAL COST } & $\mathbf{1 8 . 2 5}$ & $\mathbf{2 , 4 6 6 . 8 1}$ & $\mathbf{1 7 . 5 3}$ & $\mathbf{2 , 3 7 8 . 5 7}$ \\
\hline
\end{tabular}

Data from a collection carried out in the municipality of Crato, Ceará in July 2017 and August 2018. Adapted from CONAB (2018).

The micro-region of Crato, CE, the largest producer in 2006, with (42.34\%) of the national production is unstable in its production histories, especially in 2003, with the emergence of new management techniques, increased demand and economic interest (ROCHA et al., 2008).

For the producer, the production cost spreadsheet is a necessary tool in the analysis of costs in order to assist in decision making (VENTURA et al., 2020a). Knowledge of agricultural production costs is effective in controlling agricultural activities, as it is possible to create strategic planning in the acquisition of inputs (ARTUZO et al., 2018). Thus, Ventura et al. (2020b) recommends more descriptive and regional studies to analyze production costs to make decisions and determine the viability of the production unit regarding external demands and factors

\section{CONCLUSIONS}

The biggest reduction in production costs, per commercialization unit and per hectare of the agricultural year from 2017 to 2018 was in the municipality of Japonvar, MG.

In the municipality of Ipora, GO, there was an increase in the cost of production per commercialization unit and per hectare of the agricultural year from 2017 to 2018.

The municipality of Japonvar, MG, among the cities analyzed, presents the highest profitability in the pequizeiro culture, even if the municipality did not include the packaging.

\section{BIBLIOGRAPHIC REFERENCES}

Artuzo, FD, Foguesatto, CR, Souza, ÂRL, Silva, LX. Gestão de custos na produção de milho e soja. Revista Brasileira de Gestão de Negócios, 2018;20(2): 273-294

Afonso SR, Angelo H, Almeida AN. Characterization of Pequi production from Japonvar, MG. Floresta, 2015;45(1):49-56. doi:10.5380/rf.v45i1.33987

Boas BMV, Alves AP, Alves JÁ, Rodrigues LJ, Alves TC, Boas EVBV. Caracterização física, química e bioquímica do mesocarpo interno de frutos do pequizeiro colhidos em diferentes estádios de desenvolvimento. Ciência Rural, 2013;43(12):2285-2290. doi: 10.1590/S010384782013001200027

Brasil. Instituto Brasileiro de Geografia e Estatística. Brasil / Minas Gerais / Japonvar: Extração vegetal e Silvicultura [internet]. Brasília, DF: Instituto Brasileiro de Geografia e Estatística; 2017a [access in 23 mar. 2020]. Available in: $<$ https://cidades.ibge.gov.br/brasil/mg/japonv $\mathrm{ar} /$ pesquisa $/ 16 / 12705$ ?ano $=2017>$. 
Brasil. Instituto Brasileiro de Geografia e Estatística. Brasil / Ceará / Crato: Extração vegetal e Silvicultura [internet]. Brasília, DF: Instituto Brasileiro de Geografia e Estatística; 2017b [access in 23 mar. 2020]. Available in: < https://cidades.ibge.gov.br/brasil/ce/crato/pe squisa $/ 16 / 12705$ ? ano $=2017>$.

Brasil. Instituto Brasileiro de Geografia e Estatística. Brasil / Mato Grosso/ Poconé: Extração vegetal e Silvicultura [internet]. Brasília, DF: Instituto Brasileiro de Geografia e Estatística; 2018a [access in 23 mar. 2020]. Available in: <https://cidades.ibge.gov.br/brasil/mt/pocon e/pesquisa $/ 16 / 12705$ ? ano $=2018>$.

Brasil. Instituto Brasileiro de Geografia e Estatística. Brasil / Minas Gerais / Japonvar: Extração vegetal e Silvicultura [internet]. Brasília, DF: Instituto Brasileiro de Geografia e Estatística; 2018b [access in 23 mar. 2020]. Available in: $<$ https://cidades.ibge.gov.br/brasil/mg/japonv ar $/$ pesquisa $/ 16 / 12705$ ? ano $=2018>$.

Brasil. Instituto Brasileiro de Geografia e Estatística. Brasil / Ceará / Crato: Extração vegetal e Silvicultura [internet]. Brasília, DF: Instituto Brasileiro de Geografia e Estatística; 2018c [access in 23 mar. 2020]. Available in: < https://cidades.ibge.gov.br/brasil/ce/crato/pe squisa $/ 16 / 12705$ ? $a$ no $=2018>$.

Camargo MP, Estevam A, Feroldi M, Cremonez PA. A cultura do pequi (Caryocar brasiliense Camb.) na recuperação de áreas degradadas e como alternativa para a produção de biodiesel no Brasil. Journal of Agronomic Sciences, 2014;3:180-192.

Conab. Companhia Nacional de Abastecimento. Portal de Informações Agropecuárias -Observatório Agrícola [internet]. Brasília, DF: Companhia Nacional de Abastecimento; 2018 [access in 20 mar. 2020]. Available in: $<$ https://portaldeinformacoes.conab.gov.br/>.

Felfili JM, Ribeiro JF, Borges Filho HC, Vale AT. Potencial econômico da biodiversidade do Cerrado: estado atual e possibilidades de manejo dos recursos da flora. In: Aguia LM, Camargo AJA. Cerrado: ecologia e caracterização; 2004. Planaltina-DF: Embrapa Cerrados; 2004.

Garcia LS, Nascimento P, Guedes MNS, Souza AG, Garcia EM, Taroco HA, Melo JOF. Physical and physico-chemical characterization of pequi from the region of Sete Lagoas, MG. Scientific
Electronic Archives, 2017;10(3):6-11. doi: $10.36560 / 1032017465$

Gomes CJ. Extrativismo e biodiversidade: o caso da fava d'anta. Ciência Hoje, 2000;27:66-69.

Gulias APSM, Ribeiro JF, Oliveira MC, Aquino FG, Silva MR. Cadeia produtiva do pequi (Caryocar brasiliense Cambess.) No município de Damianópolis - GO. In: IX Simpósio Nacional Cerrado e II Simpósio Internacional de Savanas Tropicais; 2008, Brasília-DF, Anais... Brasília: Simpósio; 2008.

Melo SABX, Silva FS, Melo AX. Aspectos socioeconômico dos agricultores familiares extrativistas do cumbaru no município de Poconé-Pantanal Mato-Grossense. Revista Ibero-Americana de Ciências Ambientais, 2017;8(1):62-73. doi: 10.6008/SPC21796858.2017 .001 .0006

Mendes MF, Neves SMAS, Neves RJ, Silva TP. A organização das mulheres extrativistas na região Sudoeste mato-grossense, Brasil. Estudos Feministas, 2014;22(1):71-89.

Oliveira E, Longhi EH, Vanderlei JC, Silva IDC, Rocha E. V. Arranjo Extrativista do pequi (Caryocar brasiliense Camb.) na região de Iporá - Goiás: sustentabilidade e dinâmica da comercialização. In: Anais do $46^{\circ}$ Congresso da Sociedade Brasileira de Economia, Administração e Sociologia Rural; 2005. Ribeirão Preto: SOBER; 2005.

Oliveira E. Exploração de espécies nativas como uma estratégia de sustentabilidade socioambiental - o caso do pequi (Caryocar brasiliense Camb.) em Goiás. [doutorado] Brasília: Universidade de Brasília; 2006

Oliveira CS, Gonçalves LEN, Coutinho MP, Peixoto N, Gatto A. Aspectos Socioambientais da Comercialização de Pequi em Goiás. Floresta e Ambiente, 2017;24:e00058213. doi: $10.1590 / 2179-8087.058213$

Pozo OVC. O pequi (Caryocar brasiliense): uma alternativa para o desenvolvimento sustentável do cerrado no norte de Minas Gerais. [dissertação] Lavras: Universidade Federal de Lavras; 1997.

Ribeiro JF, Oliveira MC, Gulias, APSM, Fagg JMF, Aquino FG. Usos múltiplos da biodiversidade no Cerrado: estratégia sustentável para a 
sociedade, o agronegócio e os recursos naturais. In: Faleiro FG, Farias Neto AL (eds). Savanas: desafios, estratégias para o equilibrio entre sociedade, agronegócio e recursos naturais. Embrapa Cerrados, Planaltina, DF; 2008: $337-$ 360 .

Rocha MG, Rocha TC, Aguiar JLP, Junqueira NTV. Dinâmica da Produção Extrativista de Pequi no Brasil. In: IX Simpósio Nacional Cerrado e II Simpósio Internacional Savanas Tropicais, 2008;9, Brasília. Anais... Brasília: Simpósio; 2008.

Rodrigues LJ, Boas EVBV, Paula NRF, Alcântara EM. Caracterização do desenvolvimento de pequi (Caryocar brasiliense) temporão do sul de Minas Gerais. Pesquisa Agropecuária Tropical, 2009;39(3):260-265. doi:10.5216/pat.v39i3.4024

Santos FS, Santos RF, Dias PP, Zanão Junior LA, Tomassoni F. A cultura do Pequi (Caryocar brasiliense Camb.). Acta Iguazu, 2013;2(3):46-57.
Silva MNS. Territorialidades do Pequi: Montes Claros e o Norte de Minas em questão. In: Encontro Nacional de Geografia Agrária, 2009;19, São Paulo: Anais eletrônicos.; 2009.

Ventura, MVA, Batista, HRF, Bessa, MM, Pereira, LS, Costa, EM \& Oliveira, MHR. Comparison of conventional and transgenic soybean production costs in different regions in Brazil. Research, Society and Development, 2020a;9(7):1-15, e154973977. doi: 10.33448/rsd-v9i7.3977

Ventura, MVA, Batista, HRF, Bessa, MM, Costa, EM, Pereira, LS \& Silva, RM. Production cost of transgenic corn in the first and second harvest in different regions in Brazil. Research, Society and Development, 2020b;9(7): 1-14, e279974136. doi: $10.33448 /$ rsd-v9i7.4136 